\title{
Student Consumptive Lifestyle and Its Implications in Guidance and Counseling
}

\author{
Rahmi Azhari ${ }^{1^{*}}$, Herman Nirwana $^{2}$, Mega Iswari $^{3}$ \\ 1,2,3Universitas Negeri Padang \\ *Corresponding author, e-mail: rahmiazhari1225@gmail.com
}

\begin{abstract}
This study aims to analyze how the form of student's consumptive lifestyle, the factors that cause it, and the negative impact of the student's consumptive lifestyle. This research uses descriptive qualitative method with case study research type. The research subjects were 2 people within the scope of UIN Suska Riau students, using data collection techniques, namely in-depth interviews, observation and documentation. The data analysis technique used by researchers was guided by the Miles \& Huberman model. The results showed that the form of a consumptive lifestyle that was seen in the research subjects was excessive shopping and buying goods that did not suit their needs. The contributing factors are shopping because of discounts, likes to be admired by others, and environmental factors. As well as the negative impact of a consumptive lifestyle that occurs on the subject of the study are: low budget economy, likes to lie, becomes a person who likes to be in debt, and is negligent in doing college assignments.
\end{abstract}

Keywords: Lifestyle Consumptive, Students

How to Cite: Azhari, R., Nirwana, H., Iswari, M. 2021. Student Consumptive Lifestyle and Its Implications in Guidance and Counseling International Journal of Applied Counseling and Social Sciences, 2 (1): pp. 41-47, DOI: https://doi.org/10.24036/005395ijaccs

This is an open access article distributed under the Creative Commons 4.0 Attribution License, which permits unrestricted use

distribution, and reproduction in any medium, provided the original work is properly cited. @2021 by Author

\section{Introduction}

Humans are known as social beings, which means humans need help from other humans to meet the needs of life, both primary, secondary and tertiary (Kazeminia, Kaedi, \& Ganji, 2019). So that it can determine the role of humans as social beings towards their environment. Currently humans have experienced many changes along with the development and progress of the times in the modern era. Changes that occur such as technological developments, lifestyles, economies, and even the rules that exist in society with changing customs systems (Zhang, Qu, Sheng, Yang, Wu, \& Yuan, 2019). Adolescence is a vulnerable period with changes in the form of biological, cognitive and socioemotional changes (Karneli, Firman, \& Netrawati, 2018)

Students are part of society. The word student itself can literally be interpreted as students who have been registered in a higher education institution and have met the requirements as students set by the College. Similar to society in general or household communities, students also have needs that must be met. The picture of the student's lifestyle that is expected is to fill their time by learning to increase their knowledge, skills, expertise, and fill their activities with various kinds of positive activities so that they will have a future orientation as humans that are beneficial to society and the 
nation, by participating in various campus activities active in class, as well as in organizational matters, think rationally with existing developments, do not automatically choose satisfaction but need, are not tempted by the growing influences out there because they remain focused on their studies (Kurniawan, 2017). Environmental conditions also affect student learning processes (Dinata, Iswari, \& Mudjiran 2015).

Khaniwale (2015) in his research states there are 4 main factors that cause a person to have a consumptive lifestyle. First, culture refers to the overall way of life of a group of people from a particular society, place or time. Culture includes every aspect of life including thoughts, behavior, practices, technology, rituals, norms, language, beliefs, ethics, and lifestyle in a community group. Second, namely social, which includes the role of family and social status. Third, namely personal factors, including age, education, profession, income, personality and lifestyle. The fourth is psychology, which includes perception, motivation, learning, beliefs and attitudes.

The consumptive lifestyle of students is increasing with the rise of smart phones, where students will find it easier to reach groceries through social networks (Abrar, Bashir, Shabbir, \& Haris, 2019). According to research conducted by Chita, David, and Pali in 2015 showed that 36.2\% of 2011 Sam Ratulangi University Faculty of Medicine adolescents behaved consumptively by shopping online. This study shows that consumptive behavior does not only appear among adults, but also occurs in college students. The emergence of consumptive behavior among students is caused by the susceptibility of students to be influenced by product and service promotions through the media or directly. Environmental conditions that support students to access various forms of innovation or change in the environment due to the internet. The internet provides various facilities that make it very easy for users to access a variety of information they want so that internet users are spoiled by these various facilities, the various facilities presented by the internet provide a new color in terms of shopping (Nawi, Mamun, Hasliana, \& Hamsani, 2019).

\section{Method}

This research uses descriptive qualitative method with case study type. The research was conducted at the State Islamic University of Sultan Syarif Kasim Riau. The research subjects were two students with the criteria of having a consumptive lifestyle. The research data collection techniques were in-depth interviews, observation, and document analysis. Techniques guarantee the validity of the data, namely: (1) extending the time the researcher participates in the field, (2) increasing observation persistence, (3) triangulation, and (4) using appropriate reference materials. The data analysis techniques used were: (1) data reduction, (2) data display, (3) conclusion / verification (Miles \& Huberman model).

\section{Results and Discussion}

In this study, the focus of the problem is: 1 . Forms of student consumptive lifestyle, 2. Factors causing student consumptive lifestyle, 3 . Negative impact of student consumptive lifestyle. So the research results show that:

\section{Forms of the student's consumptive lifestyle}

There are two forms of student consumptive lifestyle:

a. Excessive shopping

Mangkunegara (2009) the characteristics of individuals having a consumptive lifestyle: 1) Want to look different from other people, 2) Shopping excessively 3) Joining. In line with this, research conducted by Prasetyo (2017) states that the large number of malls in big cities causes many students to forget their main duties. They will always follow fashion developments in the area where they live, they tend not to be confident if they don't wear new items according to the current trend. They will be more confident if they can buy and use new and trendy things with their peers. Most students are exposed to shopping addiction, which is addiction to 
shopping or shopping excessively so that it creates a high consumptive lifestyle among students.

Similar to the results of the research above, the two research subjects show their hedonistic consumptive lifestyle, research subjects often shop excessively by buying trendy items. Within a month the two research subjects bought items with the same product can repeatedly buy these items, without thinking about whether the subject already owns the goods or not. The subject shopped excessively without considering whether these items would be beneficial to him or not.

b. Buying items not as needed

Sumartono (2002) consumptive lifestyle is an act of using a product incompletely, meaning that a product has not been used yet, someone has used another product with the same function, this of course will spend more individual expenses. Products used such as bags, clothes, shoes, sandals. By buying a product whose use value is not used completely, individuals buy the same item again to fulfill their consumptive lifestyle. In line with this, the two research subjects in buying goods are also not adjusted to the needs they use. Such as the results of interviews with the two research subjects where the two research subjects bought the things they wanted. However, these items have never been used until now, just a collection and hungry eyes when buying. The consumptive lifestyle also describes the existence of a human life pattern that is controlled and driven by a desire to fulfill mere pleasures (Nurwidyawati, 2017).

2. Factors causing student's consumptive lifestyle

There are three factors that cause the student's consumptive lifestyle:

a. Shop because there are discounts

Tjiptono (in Kompasiana, 2019) a discount is a discount given by the seller to the buyer as an appreciation for certain activities of the buyer that are pleasing to the seller, the greater the discount, the more likely it is to be tempted to buy items that are less needed. From the results of the study it was revealed that the two research subjects to fulfill their consumptive lifestyle in buying goods really emphasized the existence of a discount, with the discount the research subjects thought they could buy large quantities of goods at affordable prices, from the results of the interview the researcher said initially they would buy 1 item when seeing a discount the subject ended up buying the same item as much as 3 pieces.

In line with this, according to Sutisna (2002) the objectives of giving discounts to buyers are: 1) Encouraging large purchases 2) Encouraging purchases to be made in cash or shorter time 3) Binding customers so as not to move to other companies (Manggiasih , Widiartanto, \& Prabawani, 2018). The results of research conducted by Ardianto (2017) show that out of 6 research respondents said that the discount makes shopping interest higher and the satisfaction level of buying goods in large quantities makes it more attractive in the buying and selling process.

b. Likes to be admired by others

Kartodiharjo (Kamaruddin \& Mokhlis, 2003) consumptive lifestyle as a socio-economic development is influenced by cultural factors, the importance of the role of contagious modes, besides that the attitude of a person such as people not wanting to be left behind from their friends or a cultural disease called "prestige" is often a motivation in obtaining products, sociopsychological symptoms are also found in the form of a desire to imitate so that adolescents compete that one wants to be better than the other. In line with this (Fitriyani, Widodo, \& Fauziah, 2017) students try to present something that seems "wow" in fulfilling their needs and lifestyle to gain acceptance, recognition from friends as their reference group.

The findings of the research that the researchers conducted on the research subjects of SA and IS both have personalities that really like to be praised and praised by others, with praise from other people making research subjects feel happy and want to look better in front of the 
crowd. The subject of SA during the interview said that the consumptive lifestyle of SA is getting higher because SA likes men in her class and she wants to look good in front of the people she likes. Buying products to maintain one's appearance and prestige, which is where someone who wants to have high self-esteem or status is seen in the surrounding community (Rahmayanti, 2017). In line with this (Fitriyani, Widodo, \& Fauziah, 2017) said the desire to be accepted and afraid of being excluded, encourages students to try to be the same as their peers. Like the subject of SA, IS also likes it if he is praised and admired by others, IS thinks that he will not escape people's judgments whether it is good or bad, therefore IS is very concerned about his lifestyle in appearance by using items that are according to the standard it makes IS confident to appear in front of the crowd.

c. Affected by the environment

Sumartono (2002) Using products because of the element of conformity to the advertising model. Students tend to imitate the behavior of the characters they idolize in the form of using everything their idol characters can use. Students also tend to use and try the products offered if they idolize these public figures. Therefore, any product used by his idol character will be a big consideration for students about the product they will wear. In line with the findings made by the researchers on the first research subject, namely SA, that one of the factors that causes SA to have a consumptive lifestyle is its own environment, SA likes to see the styles of artists and celebrities on social media.

During the period of student development, parents are no longer the model, but people of the same age become the main model (Nurwidyawati, 2017). Not only celebrities and artists become role models of SA, their peers are also examples of SA in a consumptive lifestyle, because they like the styles of their peers SA always follows the styles and clothes worn by their friends, therefore SA always comes with friends to shop for things they like. by them, and SA didn't think anymore about whether he had any extra money to buy these items.

A person's lifestyle is greatly influenced by family, how the lifestyle of one family member will affect the lifestyle of other family members (Gumulya \& Widiastuti, 2013). In line with that, the second research subject, namely IS, made her aunty her role in fashion, IS thought her aunt looked fashionable and fashion in dressing even though she was old, her aunt could still look fashionable. The results of research conducted by Kurniawan (2019), which is one of the factors causing the student's consumptive lifestyle, is following a developing trend, data from $40 \%$ of student respondents. In line with this, the IS subject in terms of dress also sees the surrounding environment with the presence of social media such as Instagram, YouTube, Facebook is looks at clothing models that are trending at this time.

3. The negative impact of the student's consumptive lifestyle

From the research results there are four negative impacts of the student's consumptive lifestyle:

a. Low budget economy

Lifestyle is defined as how a person lives, including how someone uses his money. How he allocates his time and so on (Cancer, 2015). To meet consumptive needs, of course, the role of the economy is very important where money comes from and where it will be used. In fact, adolescents do not do things related to their economic independence. They tend to do other things related to excessive purchases or consumptive behavior (Fitriyani, Widodo, \& Fauziah, 2017). Students need an economy to meet these needs, as well as the first and second research subjects, namely SA and IS, the allowance given by their parents for college needs is also used to fulfill their consumptive lifestyle. Parents' income is very influential in children's purchasing decisions (Kiriinya, Bwisa, \& Orwa, 2014). Like SA and IS, his parents gave him 1.5 million per month for college needs. However, the two subjects of this study used the money to fulfill their consumptive lifestyle. Even from the results of interviews conducted, the allowance given by the parents of both subjects was not enough to fulfill his consumptive lifestyle desire. Where the amount of spending with their pocket money is not in sync, the expenditure is more than 
the income. So that it has a negative impact on the two subjects who experience a low budget economy (low budget). Because it has become a habit and buying out of necessity, the two research subjects from an economic perspective, to fulfill their lifestyle, experienced a low budget.

b. Loves to lie

Sriatmini (2009) on students in Malang shows that students are prestigious and feel ashamed if they do not buy unbranded goods and they feel excluded from their friends, even though they do not have money, they will still buy these branded goods even though in an unreasonable way. students in Malang City (79.60\%) stated that they had committed negative actions such as borrowing money, stealing, bullying, cheating, lying, even committing acts of violence against others just to fulfill their shopping desires (Fitriyani, Widodo, \& Fauziah , 2017).

To stay on the axis and still fulfill their consumptive lifestyle, one of the negative impacts that occurred in the research subject was becoming a person who likes to lie, like SA IS who likes to ask for extra pocket money from parents and also lies to her siblings, with the reason to cover costs. the need for college is less, even though the items purchased by the research subject are not very important in value, even the items purchased are some that have never been used by him. The two research subjects used their pocket money to hang out with their friends such as in cafes, fast food places and others.

c. Become a person who likes to be in debt

The consumptive lifestyle is no longer concerned with something that is purchased or not for oneself, which is very bad for personalities and will make the individual experience problems, such as wastefulness and even debt to fulfill the desires of consumptive behavior (Rathore, 2018). Another negative impact that arises in the research subject is becoming a person who likes to be in debt.The results of interviews with the SA research subject said that he borrowed money from his friends and siblings to buy cellphones, because SA was still not using his UKT money to cover it, because there was no money to pay for it. reimburse the debt, the subject of SA tries to debt back to someone else. Teenagers will do their various desires to shop. A survey conducted by Deteksi Jawa Pos found that $20.9 \%$ of the 1,074 respondents who were students who were domiciled in Jakarta and Surabaya admitted that they had used their spp money to buy their target items or just for fun (Sitohang, 2009).

The difference with SA, the second research subject is that IS does not like to be in debt to other people to fulfill his consumptive lifestyle, however, IS is a person who dares to take his parents' money without permission, from interviews that researchers conducted with IS, IS has ever taken money from his mother's ATM without permission. to buy the clothes he wants in sufficient quantities, this certainly has a negative impact on IS and is what KES should become KES-T.

d. Negligent in doing college assignments

Students who have financial abilities become easily influenced to fulfill a consumptive lifestyle, students will be considered following the times if they have bought and used goods with famous brands, no longer through achievement (Fitriyani, Widodo, \& Fauziah, 2017). In line with the results of research conducted by Wahidah, Imran, and Bahari (2018) the impact of a consumptive lifestyle on lecture achievement carried out on 2 research subjects, the result is a change in the learning process or lectures carried out by the two subjects marked as not focusing on learning while playing cellphones, calling, watching TV, playing more on cellphones to find items to buy rather than studying, these changes have an impact on a low GPA. Just as the two research subjects think of their consumptive lifestyle who like shopping, gather almost every day in cafes or fast food restaurants with friends who waste enough time, do not interfere with doing campus assignments, the subject thinks that the task can be done in Time is short and fast, by taking off the internet, copied and edited, a few tasks that should be 
done well by looking at the right literature can be done in no time. This certainly had a negative impact on the two subjects who considered campus assignments to be trivial matters, which actually from the consumptive lifestyle made the two subjects negligent in doing their assignments on campus.

In line with the results of research conducted by Fisikha, 2013, it is said that students carry out learning activities without planning, controlling and evaluating their learning, resulting in individuals like to procrastinate, and collect assignments not on time (Koto \& Nirwana, 2019) Students are expected individuals who will become the nation's successor to advance the nation in the world with the abilities they have, of course, the task of students is very important for the country, this is in accordance with the opinion of Prayitno (2005) that optimally utilizing one's own abilities is a personal condition that has been able to develop five human resources for upholding it. the essence of man in himself within the frame of the human dimension, so that he becomes an individual who upholds the nature of humanity, namely believing and being obedient to the one and only god, optimally utilizing one's abilities and having high morals.

\section{Conclusion}

Based on the findings and discussion of the research results, the following conclusions can be made: The two research subjects were excessive shopping and buying goods that did not meet their needs. And Factors that affect the consumptive lifestyle of the two research subjects are buying goods because of discounts, like being admired by others and environmental factors and The negative impact of the consumptive lifestyle of the two research subjects is low budget economy, likes to lie, becomes a person who likes to be in debt, takes money without permission, and is negligent in doing college assignments.

\section{References}

Abrar, M., Bashir, M., Shabbir, R., \& Haris, M. (2019). Role of personality and social factors towards purchase of luxury clothing in online settings: moderating role of vanity. European Online Journal of Natural and Social Sciences 2, 8 (1), 42-51.

Ardianto, A. K. (2017). Moderasi gaya hidup konsumtif dalam pengaruh diskon terhadap keputusan pembelian. Tesis tidak diterbitkan. Yogyakarta: Program Pascasarjana Universitas Sanata Dharma

Dinata, M. P., Iswari, M., \& Mudjiran. (2016). Kontribusi konsep diri dan dukungan orangtua terhadap motivasi belajar siswa dan implikasinya dalam pelayanan bimbingan dan konseling. E-Journal UNP, 5 (1), 1-14.

Fitriyani, N., Widodo, P. B., \& Fauziah, N. (2017). Hubungan antara konformitas dengan perilaku konsumtif pada mahasiswa di genuk indah Semarang. E-Journal Universitas Diponegoro, 275 (3), 55-68.

Gumulya, J., \& Widiastuti, M. (2013). Pengaruh konsep diri terhadap perilaku konsumtif mahasiswa. Prosiding SNaPP2013 Sosial, Ekonomi, Dan Humaniora, 176 (5), 1-16.

Hasibuan, E. (2010). Hubungan antara gaya hidup brand minded dengan kecenderungan perilaku konsumtif pada remaja putri. Jurnal Media Wahana Ekonomika, 56 (4), 12-34.

Kamaruddin, A. R., \& Mokhlis, S. (2003). Consumer socialization, social structural factors and decision making styles: a case study of adolescent in Malaysia. International Journal of Consumers Studies, 27 (2), 145-156

Kanserina, D. (2015). Pengaruh literasi ekonomi dan gaya hidup terhadap perilaku konsumtif mahasiswa jurusan pendidikan ekonomi UNDIKSHA. Jurnal Media Wahana Ekonomik, 5 (1), 111

Karneli, Y., Firman., \& Netrawati. (2018). Upaya guru BK/Konselor untuk menurunkan perilaku agresif siswa dengan menggunakan konseling kreatif dalam bingkai modifikasi kognitif perilaku. Pedagogi: Jurnal Ilmu Pendidikan, 18 (1), 1-7. 
Kazeminia, A., Kaedi, M., \& Ganji, B. (2019). Personality-based personalization of online store features using genetic programming: analysis and experiment. Journal of Theoretical and Applied Electronic Commerce Research, 14 (1), 1-14

Khaniwale, M. (2015). Consumer buying behavior. International Journal of Innovation and Scientific Research, 14 (2), 278-286.

Kiriinya, S, N., Bwisa, H., \& Orwa, G. O. (2014). Children's peer group influence on family purchase decisions in Kenya. International Journal of Advanced Research in Management and Social Sciences, 3 (11), 327-338.

Kompasiana. 2019. Pengaruh diskon terhadap perilaku konsumtif. (Online), Vol.3, No I, (http://lovepik.kompasiana.com, diakses 18 Januari 2021).

Koto, T., \& Nirwana, H. (2019). Perbedaan pengaturan diri dalam belajar pada mahasiswa pria dan wanita. Jurnal Riset Psikologi, 4 (1), 1-13.

Kurniawan , C. (2019). Analisis faktor-faktor yang mempengaruhi perilaku konsumtif ekonomi pada mahasiswa. Jurnal Media Wahana Ekonomika, 13 (4), 11-26

Manggiasih, F. P., Widiartanto, \& Prabawani, B. (2018). Pengaruh discount, merchandising, dan hedonic shopping motives terhadap impulse buying. Jurnal Media Wahana Ekonomika, 12 (1), 1-11.

Mangkunegara (2009). Perilaku Konsumen. Bandung: Refika Aditama.

Nawi, N. C., Mamun, A. A., Hasliana, N., \& Hamsani, B. (2019). Effect of consumer demographics and risk factors on online purchase behaviour in Malaysia. Societies Mdpi, (Januari 2019), 28 (3), 111.

Nurwidyawati, R. (2013). Mengatasi konsumtif melalui konseling behaviosristik pada siswa. Prosiding SNaPP2013 Sosial, Ekonomi, dan Humaniora, 2 (1), 1-12.

Prasetyo, Y. (2017). Gaya hidup dan shopping addiction. Jurnal Psikologi Indonesia. 6 (2), 1-8.

Prayitno. (2005). Pembelajaran Melalui Layanan BK di Satuan Pendidikan. Yogyakarta: Paramitra

Rahmayanti, D. (2017). Online shop dan perilaku konsumtif mahasiswi jurusan pendidikan IPS Fakultas Ilmu Tarbiyah dan Keguruan UIN Syarif Hidayatullah Jakarta. Tesis tidak diterbitkan. Jakarta: Program Pascasarjana UIN Syarif Hidayatullah

Rathore, A. (2018). Behavioral economics in management decision making. International Journal of Engineering and Management Research, 8 (6), 176-181.

Sitohang, A. (2009). Hubungan antara konformitas terhadap kelompok teman sebaya dengan pembelian impulsif pada remaja. Tesis tidak diterbitkan. Semarang: Program Pascasarjana Universitas Diponegoro

Sumartono. (2002). Terperangkap dalam iklan (Meneropong Imbas Pesan Iklan Televisi). Bandung: Alfabeta.

Wahidah, R., Imran., Bahari, Y. (2018). Dampak gaya hidup knsumtif pada kehidupan sosial dan prestasi mahasiswa. Tesis tidak diterbitkan. Pontianak: Program Pascasarja Pendidikan Sosiologi FKIP Untan Pontianak.

Zhang, L., Qu, J., Sheng, H., Yang, J., Wu, H., \& Yuan, Z. (2019). Resources, conservation \& recycling urban mining potentials of university: in-use and hibernating stocks of personal electronics and students disposal behaviors. Resources, Conservation \& Recycling, 143 (July 2018), 21 (1), 210-217. 